\title{
Use of Phanerochaete Chrysosporium in a Semibatch Reactor for Removal of Indigo Carmine from Synthetic Textile Wastewater
}

\author{
Andreza Dnarla Oliveira Santos ${ }^{1 *}$ \\ https://orcid.org/0000-0003-1765-9269
}

\section{Leonardo Bandeira ${ }^{2}$}

https://orcid.org/0000-0001-7220-9194

Glória Maria Marinho Silva ${ }^{3}$

http://orcid.org/0000-0002-2515-5856

\section{Carlos Ronald Pessoa Wanderley ${ }^{4}$}

http://orcid.org/0000-0002-7298-872X

\section{Kelly Rodrigues ${ }^{3}$}

http://orcid.org/0000-0003-4340-0269

${ }^{1}$ Federal University of Ceará, Graduate Program in Civil Engineering, Fortaleza, Ceará, Brazil; ${ }^{2}$ Graduate Program in Ecology and Natural Resources, Fortaleza, Ceará, Brazil; ${ }^{3}$ Federal Institute of Education, Science and Technology of Ceará, Campus Fortaleza, Fortaleza, Ceará, Brazil; ${ }^{4}$ Federal Institute of Education, Science and Technology of Ceará, Campus Maracanaú, Maracanaú, Ceará, Brazil.

Editor-in-Chief: Paulo Vitor Farago

Associate Editor: Ana Cláudia Barana

Received: 2020.08.04; Accepted: 2021.02.24.

*Correspondence: andrezadnarla@gmail.com; Tel.: +55-85-33073750 (A.D.O.S.).

\section{HIGHLIGHTS}

- The semibatch reactor is presented as a new arrangement for fungal bioreactors;

- The removal of dye was accompanied by the removal of organic matter in terms of chemical oxygen demand (COD);

- The fungi showed high affinity with the polyurethane foam, distributing itself throughout the foam and not restricted only to the surface layer of the support medium;

- The fungal community remains dominant through bacterial contamination.

Abstract: The textile industry demonstrates a polluting potential from the planting of cotton to the release of wastewater. The presence of dyes in water bodies decreases the passage of sun rays and directly affects the photosynthetic organisms and the ecosystem. Fungi have potential in the treatment of wastewater containing dyes with complex organic structures due to enzymes that they produce. This study evaluated the 
use of Phanerochaete chrisosporium in the treatment of synthetic effluent from textile industry containing indigo carmine $(20 \mathrm{mg} / \mathrm{L})$. The fungus was immobilized in a semibatch reactor. Glucose was the cosubstrate employed in the experiment and it was used in the system at $1 \mathrm{~g} / \mathrm{L}$ at the beginning of the process and $0.5 \mathrm{~g}$ $/ L$ after 24 hours of reaction. Average dye removal was $84 \pm 10 \%$ and chemical oxygen demand removal was $79 \pm 14 \%$. For nitrogen compounds, the removal efficiencies were $87 \pm 11 \%, 81 \pm 11 \%$ and $91 \pm 9 \%$ for ammonia, nitrite and nitrate, respectively. The $\mathrm{pH}$ of the medium remained in the acidic range (2.57 to 5.00$)$ throughout the process, with the lowest values recorded in the effluent of each cycle, justified by the release of organic acids from fungi metabolism. There was contamination of the medium by bacteria $(710,000 \mathrm{CFU} / \mathrm{mL})$, but the colonies count showed a predominance of fungi $(1,365,000 \mathrm{CFU} / \mathrm{mL})$. With the use of the semibatch system after reading of glucose it was observed that the efficiency of dye removal evolved from $72 \pm 17 \%$ to $84 \pm 10 \%$, producing a final effluent with $3.35 \pm 1.99 \mathrm{mg} / \mathrm{L}$ of indigo, which proves that treatment configuration analyzed is satisfactory for dye removal.

Keywords: glucose; indigo carmine; mycoremediation; Phanerochaete chrysosporium; semibatch.

\section{GRAPHICAL ABSTRACT}

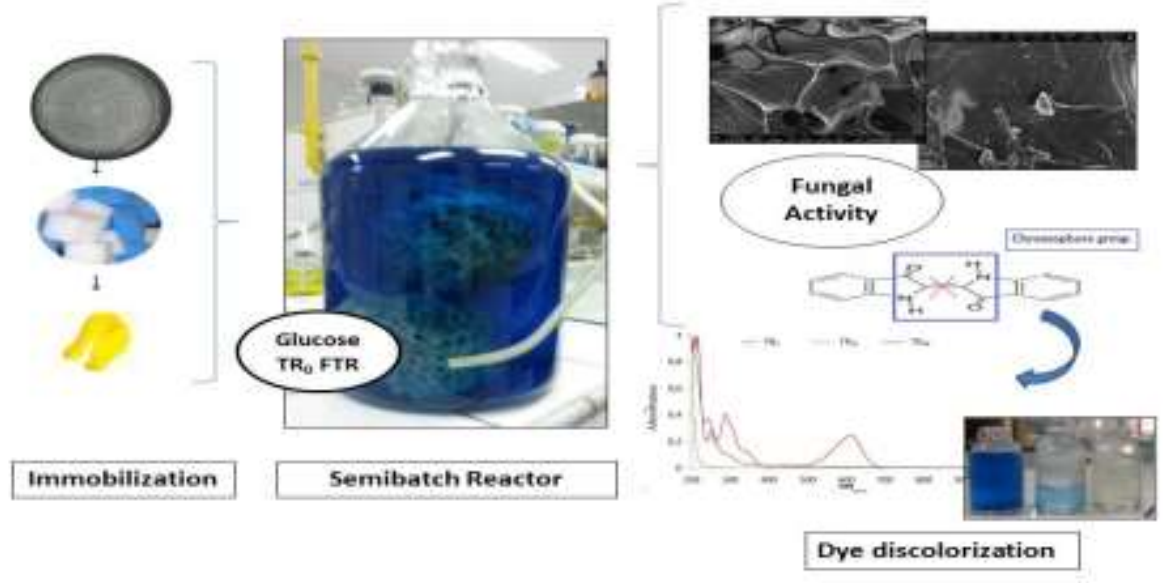

\section{INTRODUCTION}

Maintaining the quality of natural water bodies is a great environmental challenge. A high number of potentially toxic and dangerous substances are generated as a result of the intensive industrialization process, being present in inadequately disposed wastewater, which causes contamination and negative impact on the environment [1].

The textile industry contributes to water pollution. During the textile processes large amounts of liquid effluents rich in synthetic dyes and with high concentrations of surfactants and additives are generated. These effluents have complex molecules and high concentrations of total solids, most of which are dissolved solids $[2,3]$.

The contamination of water bodies by textile effluents largely affects the aquatic environment. Textile effluents change the absorption of light and the ideal oxygen circulation on water bodies, which causes a negative impact on photosynthetic processes and other physiological processes of plants, diatoms and algae[4]. This scenario requires the correct management of water resources, with the treatment of liquid effluents and their adequate disposal.

Several techniques are employed for the treatment of textile effluents. Physicochemical methods are often the most used such as chemical coagulation and/or flotation processes for the removal of particulate solids [2]. Activated carbon can be used for the removal of dissolved organic matter and color. While these operations are highly efficient, they are also very costly [5].

Biological processes are an alternative to the methods usually employed in wastewater treatment and can provide not only the degradation of recalcitrant organic compounds, such as dyes, but also be more efficient and economically viable. The application of filamentous fungi in the bioremediation of dyes has been widely studied $[6,7,8]$. These organisms can be used in the biological degradation of different water pollutants, such as dyes. Filamentous fungi are abundantly present in the environment and can adapt their metabolism 
to diferente carbon and nitrogen sources [9]. Among white fungi, Phanerochaete chrysosporium has a prominent place due to the production of ligninolytic enzymes and their rapid growth [10] .

The control of operational parameters such as $\mathrm{pH}$, aeration, temperature, reactor configurations, addition of primary carbon sources, macronutrients and micronutrients are crucial for the stability and efficiency of a bioreactor. The discoloration process becomes more efficient in the presence of a readily assimilable organic carbon source, which improves discoloration efficiency due to the formation of highly reactive compounds by the addition of glucose [11]. Glucose as a cosubstrate can improve the dye assimilation by microorganisms, which increasing decolorization [12,13]. Glucose can also be an efficient and better carbon source for discolorization than other sources [14].

The presence of a carbon source of easy assimilation in the cultivation medium is important for the biodegradation process, as this influences the microbial metabolism providing energy for metabolic activities. The cosubstrate acts as a cometabolite during the enzymatic action, inducing synthesis or enzymatic activity, which occurs during the secondary metabolism for the degradation of the pollutant [15-18].

The objective of this research was to evaluate the impact of semibatch feeding on reactor with immobilized Phanerochaete chrysosporium biomass for the removal of indigo carmine. Glucose was the cosubstrate used and it was kept in the cultivation medium over the operating cycles to promote better dye removal efficiency.

\section{MATERIAL AND METHODS}

\section{Microorganism culture and spore production}

The cultivation of Phanerochaete chrysosporium was performed using a growth medium with the following composition (g/L): yeast extract (2.0), glucose (20.0), K2HPO4 (20.0), KH2PO4 (0.6), MgSO4 (0.5) and peptone (2.0). The medium was deposited in sterilized Petri dishes (previously autoclaved at $121^{\circ} \mathrm{C}$ for 20 minutes), and then the microorganisms were inoculated in them, as described by [19].

The Petri dishes were kept in a microbiological oven at $28^{\circ} \mathrm{C}$ for one week. After the sporulation period, the spores grown were removed with isotonic saline solution and Tween $80(\mathrm{v} / \mathrm{v})$ using a Drigalski spatula. The fungus was used in the form of a suspension with a concentration of $2 \times 106$ spores $/ \mathrm{mL}$.

The Phanerochaete chrysosporium used in this study was obtained from the LATAM microbial collection from the Federal Institute of Education, Science and Technology of Ceará (IFCE) and is registered in the National System of Management of Genetic Heritage and Associated Traditional Knowledge (Sisgen) with the code A40355A.

\section{Immobilization of Phanerochaete chrysosporium in support and starting of the reactor}

Polyurethane foam $(15 \mathrm{~g})$ was used as a support material for the immobilization procedures. The foam was cut in cubes of $1 \mathrm{~cm}$ of edges. The foams were washed with distilled water and sterilized at $121^{\circ} \mathrm{C}$ for 20 minutes. Later, the support medium was placed in polyethylene mesh, then placed in a Duran flask $(5 \mathrm{~L})$ containing the growth medium with the composition showed in table 1 and described in [19].

Table 1. Composition of the growth medium for the Phanerochaete chrysosporium.

\begin{tabular}{cc}
\hline Components & Concentration (g/L) \\
\hline $\mathrm{Glucose}$ & 5,00 \\
$\mathrm{NaNO}_{3}$ & 0,25 \\
$\mathrm{MgSO}_{4} .7 \mathrm{H}_{2} \mathrm{O}$ & 1,00 \\
$\mathrm{CaCl}_{2} . \mathrm{H}_{2} \mathrm{O}$ & 0,04 \\
$\left(\mathrm{NH}_{4}\right) \mathrm{SO}_{4}$ & 0,50 \\
$\mathrm{KH}_{2} \mathrm{PO}_{4}$ & 2,00 \\
$\mathrm{H}_{2} \mathrm{MoO}_{4}$ & 0,02 \\
$\mathrm{MnSO}_{4}$ & 0,02 \\
$\mathrm{Fe}_{2}\left(\mathrm{SO}_{4}\right)_{3}$ & 0,02 \\
$\mathrm{ZnSO}_{4} .7 \mathrm{H}_{2} \mathrm{O}$ & 0,01 \\
\hline
\end{tabular}

The spore suspension $\left(1,7 \times 10^{9} \mathrm{spore} / \mathrm{mL}\right)$ was introduced into the reactor and, to prevent contamination during this introduction, a Bunsen burner was used. The system remained without aeration during the first 24 hours in order to facilitate the fixation of the spores to the support material. After this period, aeration was introduced to the biological reactor by micro air compressors. 


\section{Operation of the semibatch biological reactor}

The reactor was operated in semibatch with 48 hour operating cycles, using a reaction volume of $4 \mathrm{~L}$. At the beginning of the operational cycle (RTo) $1 \mathrm{~g} / \mathrm{L}$ of glucose was added to the system, after $24 \mathrm{~h}$ of operation a sample of $20 \mathrm{~mL}$ (IRT) was taken from the reactor and $0.5 \mathrm{~g} / \mathrm{L}$ of cosubstrate (glucose) was added to it. The reactor was fed each cycle with synthetic effluent consisting of indigo carmine dye $(20 \mathrm{mg} / \mathrm{L}), 10 \mathrm{~mL}$ of micro nutrient solution and the medium with the following composition (g/L): $\mathrm{KH}_{2} \mathrm{PO}_{4}(0.2) ; \mathrm{MgSO}_{4} .7 \mathrm{H}_{2} \mathrm{O}$ (0.5); $\mathrm{CaCl} . \mathrm{H}_{2} \mathrm{O}(0.1) ;\left(\mathrm{NH}_{4}\right)_{2} \mathrm{SO}_{4}(0.2)$.

\section{Reactor monitoring}

The reactor monitoring was performed by operating cycles of 48 hours with a total of 12 cycles. Three samples were taken from the reactor for analytical monitoring at each cycle. The samples taken from the affluent and effluent of the reactor were standardized according to their respective reaction times as follows: $\mathrm{RT}_{0}$ (affluent to the biological reactor in reactional time 0); IRT (after 24 hours of operation of the reactor) and FRT (effluent to the biological reactor in reactional time of 48 hours). At the end of the study, 36 samples were analyzed and all the analyses were performed in duplicates.

To monitor the biological treatment, physicochemical analysis of $\mathrm{pH}$, ammonia, nitrate, nitrite, organic carbonaceous material, dye and glucose were conducted. These analyzes followed the procedures described in [20], except nitrate, dye and glucose. Nitrate analyses were performed according to [21]. The dye concentration was estimated using a spectrophotometer with absorbance reading $(\lambda: 610 \mathrm{~nm})$, according to the method described by [22]. Glucose was determined according to the procedure for the determination of reducing sugars using 3,5- Dinitrosalicylic Acid (DNS). Glucose concentration was measured by constructing a standard curve obtained from standard glucose solution $(1 \mathrm{~g} / \mathrm{L})$.

Samples were taken from the support medium at the end of the reactor operation. These samples contained adhered fungal biomass, which were prepared and submitted to growth in petri dishes, by culturebased method (the colony forming unit - CFU), in order to confirm the presence of the initially inoculated fungal species and identify the possible presence of another fungal species by contamination, using standard serial dilution spread plate method on PDA medium [20], as performed by [19].

\section{Analysis of dye removal by UV-Vis spectrophotometry}

Observation of spectrophotometric behavior of absorption bands was made on all samples of the study at the reactor startup (RTo), after 24 hours of operation before (IRT) and at the end of the reaction cycle (FRT). This procedure was performed with the filtered samples to estimate the efficiency of the reactor, with scans in a UV-Vis spectrophotometer, at wavelengths of 200 to $800 \mathrm{~nm}$.

\section{Dye adsorption test in the biofilm}

A foam cube containing immobilized fungal biomass was removed from the reactor and transferred to na Erlenmeyer containing saline solution and glass beads. After this process, the cube was subjected to vigorous stirring to separate the biomass from the medium. The medium was centrifuged at $3500 \mathrm{rpm}$ for 15 min and the supernatant was separated from the biomass. Ethanol was used as solvent for the removal of the adsorbed dye in the biomass. $10 \mathrm{~mL}$ of ethanol was transferred along with the biomass to glass tubes and remaining in contact for $10 \mathrm{~min}$. After this time, another $5 \mathrm{~mL}$ of ethanol was added into sample, followed by homogenization and spectrophotometric measurement at $610 \mathrm{~nm}$ [19].

\section{Saturation test on support material}

The Polyurethane foam cubes $(5 \mathrm{~g})$, with $1 \mathrm{~cm}$ of edge were previously washed and dried at approximately $50^{\circ} \mathrm{C}$ for 120 minutes. The cubes were introduced in a $4 \mathrm{~L}$ glass bottle. After these procedures, $0.05 \mathrm{~g} / \mathrm{L}$ of indigo carmine dye was added to a glass bottle with culture medium. The maximum capacity of the polyurethane foam to adsorb the dye was monitored for $48 \mathrm{~h}$ from a known concentration, as the procedures described in [19].

\section{Scanning Electron Microscopy}

Scanning electron microscopy (SEM) was used on polyurethane foams removed from the reactor at the end of the experiment. The foams were previously prepared with the addition of carbon tape and then packed in a vacuum desiccator. The foams were subjected to the metallization process after 5 days and were gold 
plated in Quorum Q150T ES metallizer. After five days of metallization, the scans were carried out in equipment Quanta-FEG FEI (20000 kv) scanning electron microscope.

\section{RESULTS}

The characterization of the affluent and the aliquots removed from the reactor at study reaction times RTo and IRT and the final effluent (FRT) for the 12 cycles of operation (6 weeks) are shown in Table 2.

Table 2. Monitoring data from the semibatch biologic reactor (SBR) with fungi over the operating cycles.

\begin{tabular}{ccccc}
\hline VARIABLE & $\mathbf{R T}_{\mathbf{0}}(\mathbf{m g} / \mathbf{L})$ & $\mathbf{I R T}(\mathbf{m g} / \mathbf{L})$ & FRT (mg/L) & REMOVAL EFFICIENCY $_{(48)}(\%)$ \\
\hline Dye & $20.30 \pm 0,36$ & $5.77 \pm 3.50$ & $3.35 \pm 1.99$ & $84 \pm 10$ \\
pH & $5.00 \pm 0.05$ & $2.63 \pm 0.37$ & $2.57 \pm 0.36$ & $\mathrm{ND}^{*}$ \\
COD & $1035 \pm 21$ & $292 \pm 128$ & $218 \pm 140$ & $79 \pm 14$ \\
Ammonia & $59.44 \pm 8.22$ & $\mathrm{NM}^{* *}$ & $7.73 \pm 6.80$ & $87 \pm 11$ \\
Nitrite & $3.18 \pm 0.76$ & $\mathrm{NM}$ & $0.55 \pm 0.36$ & $81 \pm 11$ \\
Nitrate & $5.67 \pm 0.69$ & $\mathrm{NM}$ & $0.50 \pm 0.50$ & $91 \pm 9$ \\
\hline
\end{tabular}

$\mathrm{ND}^{*}$ No data $/ \mathrm{NM}^{* *}$ Not Monitored

The semibatch reactor used was efficient in the removal of indigo carmine dye in all operating cycles. The average concentration of the dye was $20 \pm 0.36 \mathrm{mg} / \mathrm{L}$ at the start of treatment and the average concentration decreased to $5.77 \pm 3.73 \mathrm{mg} / \mathrm{L}$ after 24 hours of reaction. After $48 \mathrm{~h}$ the average dye removal was $3.35 \pm 1.99 \mathrm{mg} / \mathrm{L}$. The overall dye removal efficiency after 24 hours of operation was $72 \pm 17 \%$ and $84 \pm 10$ $\%$ after 48 hours, at the end of cycles (Figure 1). It was observed that the best removal efficiency occurred during the first 24 hours of operation $(72 \pm 17 \%)$.

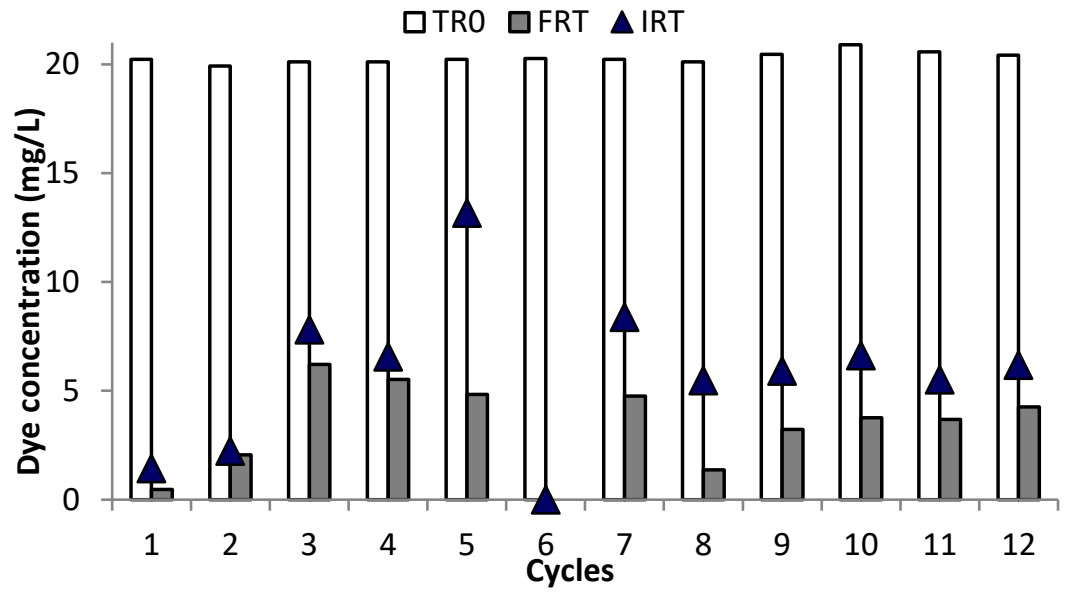

(a)

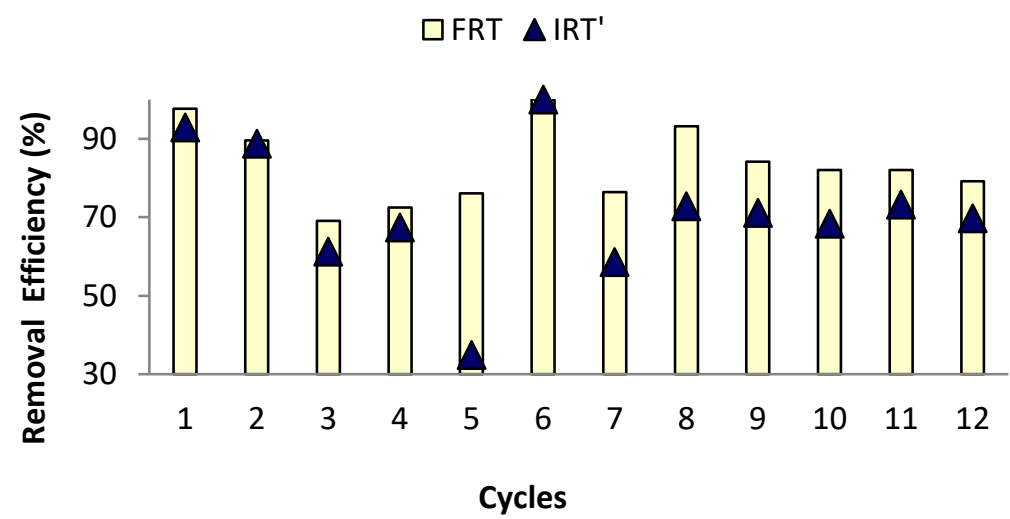

(b)

Figure 1. The overall dye removal the operating cycles: (a) Dye concentration in $R T_{0}$, IRT and FRT; (b) Dye removal efficiency IRT and FRT. 
Calculating the mass balance, the indigo dye mass input to the reactor was $892 \mathrm{mg}$. The dye concentration removed after the treatment was $145 \mathrm{mg}$. Therefore, the total mass retained in the reactor was $746 \mathrm{mg}$.

Saturation test was used to obtain the maximum adsorption capacity of the polyurethane foam, which was $3.15 \mathrm{mg}$ of dye per gram. The total mass removed from the dye by adsorption in the culture medium was $47.34 \mathrm{mg}$.

The biofilm mass adhered by mass of polyurethane foam inside the reactor was 3.64 grams per gram at the end of the experiment. This biomass had the ability to adsorb $0.65 \mathrm{mg}$ of dye per gram, according to the adsorption test described in item 2.7. Thus, all the biomass fixed on the support medium adsorbed $2.37 \mathrm{mg}$ mass of dye.

The adsorption of dye to the mycelium represented only $0.27 \%$. The polyurethane foam adsorbed $5.31 \%$ of the dye mass. The biological system was responsible for the removal of $696 \mathrm{mg}$ of dye mass, which is $78 \%$ of the indigo dye mass affluent to the reactor.

Cycles 5 and 7 showed residual dye concentration of $13.17 \mathrm{mg} / \mathrm{L}$ and $8.37 \mathrm{mg} / \mathrm{L}$ respectively in the first 24 hours of treatment. These results did not follow the higher dye removal efficiency in the first 24 hours observed in the other cycles.

None of the operating cycles showed increased dye concentration in the final effluent when compared to the dye concentration at the beginning of the cycle. This resulted in a clarified effluent (Figure 2), verified by the scanning of the affluent and the effluent (Figure 3), which revealed the reduction of the spectrophotometric bands in the length referring to the chromophore group $(\lambda: 610 \mathrm{~nm})$.
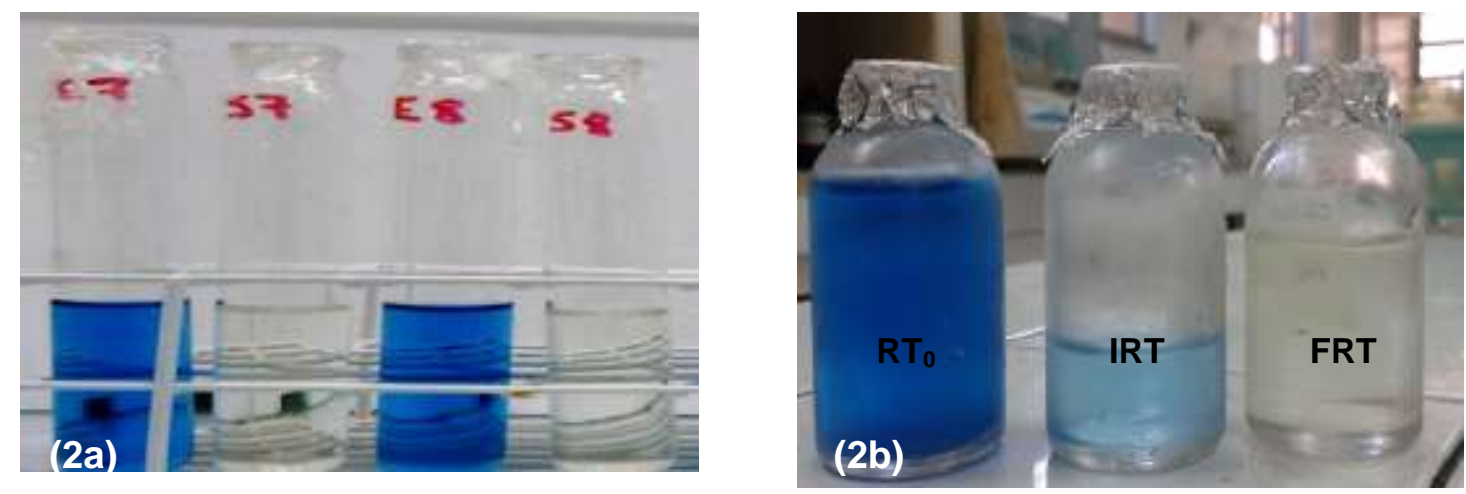

Figure 2. Flasks with affluent and effluent samples: at the end of the treatment $(2 \mathrm{a})$ and along the treatment (RT0, IRT and FRT ) in the bioreactor (2b).

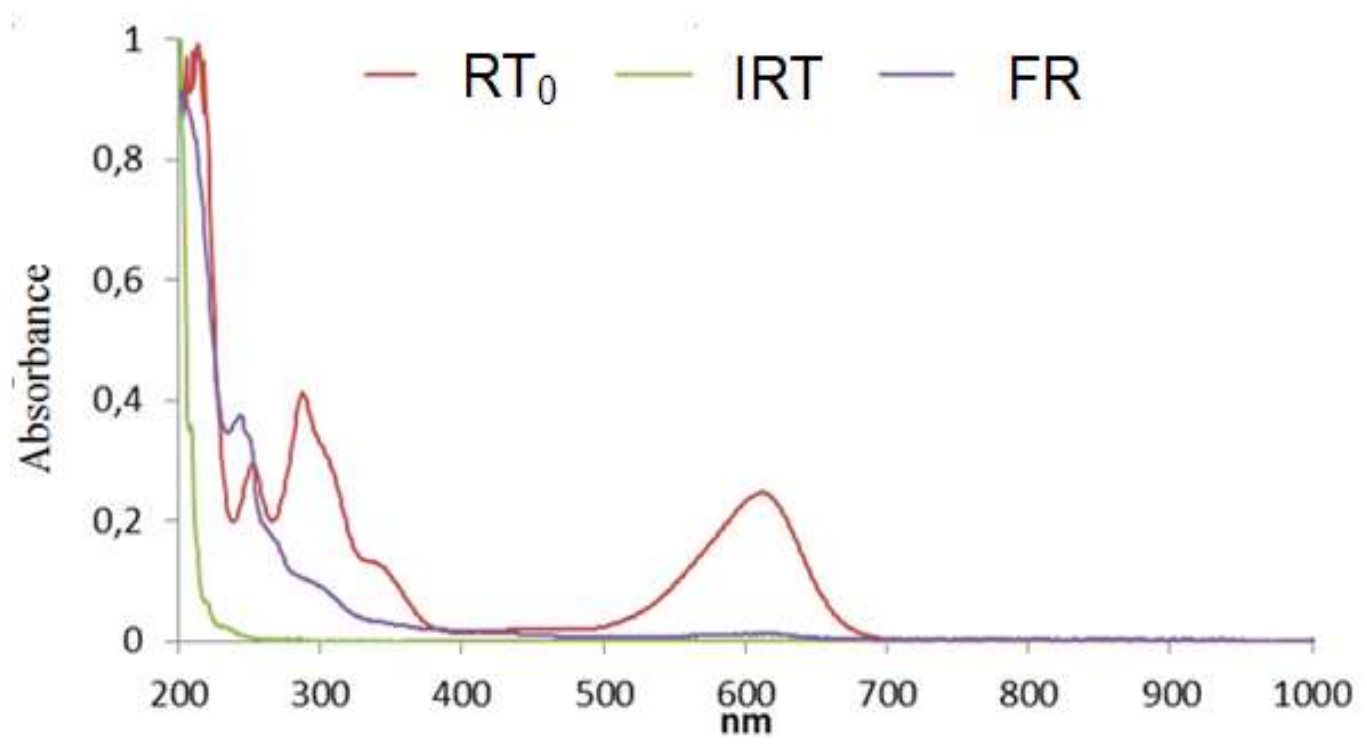

Figure 3. Scanning of the affluent $R T_{0}$, IRT and effluent Cycle 6 (FRT). 
The scanning (Figure 3) also showed that, particularly in relation to the structure of the benzene ring $(\lambda$ : $233 \mathrm{~nm}$ ), there was a decrease in the spectral band, indicating that this compound ruptured its structure. Although the benzene ring presented greater stability, due to the persistence of the carbon-carbon bonds and the symmetry of the aromatic ring [23], this would have occurred due to the biodegradation process.

A spectral band (200-250 nm) appeared between the treatments IRT and FRT, parallel to the decrease of the spectral band related to the indigo chromophore. This behavior showed a formation of byproducts from the degradation of the dye, such as sulfonic acid, which presents the main UV-visible range at $245 \mathrm{~nm}$ [24]

Despite the formation of byproducts from the disruption of the dye molecule and of the organic acids produced by the fungi by glucose consumption as a carbon source, there was removal of dissolved carbonaceous organic matter, which is measured in COD (Figure 4).

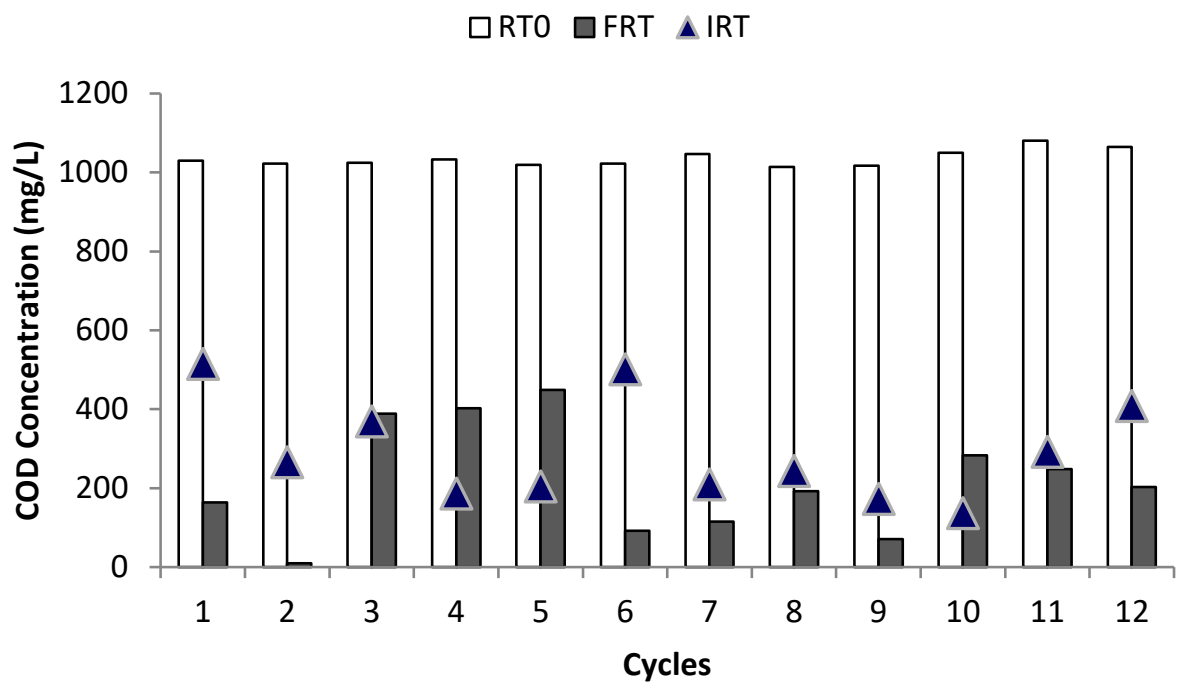

Figure 4. COD decay in the filtered samples over the operating cycles.

COD removal followed the dye removal in the medium (table 3 ). This indicates that not only the chromophore group was removed but also possibly other components of the molecular structure of índigo carmine and other substances generated by fungal metabolismo [25].

Table 3. Dye and COD removal over the biological treatament.

\begin{tabular}{ccccccccc}
\hline \multirow{2}{*}{ Cycles } & \multicolumn{3}{c}{ Dye (mg.L) } & \multicolumn{3}{c}{ COD (mg.L') } & \multicolumn{2}{c}{ Efficiency (\%) } \\
\cline { 2 - 9 } & $\mathbf{R T}_{\mathbf{0}}$ & IRT & FRT & $\mathbf{R T}_{\mathbf{0}}$ & $\mathbf{I R T}$ & $\mathbf{F R T}$ & Dye & COD \\
\hline $\mathbf{1}$ & 20.24 & 1.43 & 0.47 & 1030 & 515 & 164 & 97.70 & 84.10 \\
$\mathbf{2}$ & 19.93 & 2.24 & 2.06 & 1022 & 266 & 10 & 89.64 & 99.00 \\
$\mathbf{3}$ & 20.12 & 7.80 & 6.22 & 1025 & 369 & 389 & 69.09 & 62.00 \\
$\mathbf{4}$ & 20.12 & 6.56 & 5.53 & 1033 & 186 & 403 & 72.53 & 61.00 \\
$\mathbf{5}$ & 20.24 & 13.17 & 4.83 & 1020 & 204 & 449 & 76.12 & 56.00 \\
$\mathbf{6}$ & 20.26 & 0.00 & 0.00 & 1023 & 501 & 92 & 100 & 91.00 \\
$\mathbf{7}$ & 20.24 & 8.38 & 4.76 & 1047 & 209 & 115 & 76.47 & 89.00 \\
$\mathbf{8}$ & 20.12 & 5.46 & 1.37 & 1014 & 243 & 193 & 93.18 & 81.00 \\
$\mathbf{9}$ & 20.45 & 5.92 & 3.23 & 1017 & 173 & 71 & 84.19 & 93.00 \\
$\mathbf{1 0}$ & 20.91 & 6.61 & 3.76 & 1050 & 137 & 284 & 82.02 & 73.00 \\
$\mathbf{1 1}$ & 20.57 & 5.51 & 3.69 & 1080 & 291 & 248 & 82.07 & 77.00 \\
$\mathbf{1 2}$ & 20.43 & 6.18 & 4.26 & 1065 & 408 & 203 & 79.14 & 80.94 \\
\hline
\end{tabular}

The average COD removal efficiency was $73 \pm 13 \%$ in the first 24 hours of treatment and $79 \pm 14 \%$ for the final effluent. The average concentration of COD was $1033 \pm 19 \mathrm{mg} / \mathrm{L}$ and $281 \pm 129 \mathrm{mg} / \mathrm{L}$ after 24 hours of operation. The final effluent had $220 \pm 147 \mathrm{mg} / \mathrm{L}$ of COD in the filtered samples. 
Glucose consumption was also reflected in COD values. The added glucose was consumed almost completely throughout the operating cycles. When performing the theoretical calculation, COD attributed by glucose presented the mean concentration in RT0 of $937.7 \pm 202 \mathrm{mg} \mathrm{CODglucose} / \mathrm{L}$. After 24 hours of operation, in IRT, the concentration decreased to $88 \pm 288 \mathrm{COD}$ glucose/L. The glucose was totally consumed in cycles 4, 5, 8 and 9 .

The concentration of COD glucose declined to $41.6 \pm 51 \mathrm{mg} / \mathrm{L}$ at 48 hours of reaction time (FRT), resulting in a mean COD removal percentage of $91 \pm 28 \%$ in the first 24 hours and $92 \pm 9 \%$ for the last 24 hours of the operating cycle. In this condition, by-products from fungal metabolism and dye degradation were the major contributors of the final COD concentration.

The average COD removal efficiency achieved in the present study $(79 \pm 14 \%)$ was higher than that found in some studies on the use of fungi in dye removal, as shown in Table 4, approaching the percentages of removal of others, but it is necessary to evaluate the conditions of each research.

Table 4. COD removal efficiency in research with fungi used in the removal of textile dyes.

\begin{tabular}{|c|c|c|c|c|}
\hline Authors & Substrate & Fungi & $\begin{array}{l}\text { Time } \\
\text { (days) }\end{array}$ & $\begin{array}{c}\text { COD } \\
\text { Efficiency } \\
(\%)\end{array}$ \\
\hline Present study & Indigo carmim dye & $\begin{array}{l}\text { Phanerochaete } \\
\text { chrysosporium }\end{array}$ & 2 & 79 \\
\hline [26] & Textile Effluent - Reactive Orange 16 & Ganoderma sp. & 10 & 61.6 \\
\hline [27] & Real textile wastewater & Penicillium glabrum & 3 & 69.8 \\
\hline [28] & Industrial textile effluent (ITE) - Índigo jean & Chaetomium globosum & 5 & 88.4 \\
\hline [29] & Textile Effluent -Acid Red 357 & $\begin{array}{l}\text { Trametes villosa SCS- } \\
10\end{array}$ & 11 & 74 \\
\hline
\end{tabular}

This study also presented higher percentages of COD removal compared to other similar researches, such as cycle $6(91 \%)$, cycle $7(89 \%)$ and cycle $9(93 \%)$, showing the efficiency of the proposed treatment.

The $\mathrm{pH}$ values in the reactor remained in the acidic range during all the operational cycles. White-rot fungi, such as Phanerochaete chrysosporium employ phenol oxidase group enzymes such as lignin peroxidase (LiP), manganese peroxidase $(\mathrm{MnP})$ and laccases in the discoloration process [30]. The lignolytic enzymes exhibit maximum activity at low $\mathrm{pH}$, thus the acidity conditions in the medium lead to the best dye removal results. It is observed that for most fungi the ideal $\mathrm{pH}$ for discoloration is in the acidic range[31].

The $\mathrm{pH}$ of the affluent was $5.0 \pm 0.05$. After 24 hours of reaction there was a decrease of $\mathrm{pH}$, which reached around 2.63, with maximum of 3.1 in cycle 6 and minimum of 1.84 in cycle 1 . However, in the subsequente 24 hours, there was little change in $\mathrm{pH}$, with the final effluent of the cycles presenting an average value of $2.57 \pm 0.36$, with a maximum of 3.33 and a minimum of 1.9 , for cycles 5 and 1 , respectively.

The system was efficient in removing nitrogen with good percentages of ammonia, nitrogen and nitrate removal in all cycles of operation.

The average ammoniacal nitrogen removal efficiency in the system was $87 \pm 11 \%$, with a maximum of $97 \%$ (cycle 10) and a minimum of $60 \%$ (cycle 12). The average nitrate removal efficiency was $91 \pm 9 \%$, with a maximum of $100 \%$, in cycles 4 and 10 , and mean removal efficiency of $81 \pm 11 \%$, with a maximum of $96 \%$ (cycle 11) and minimum of $62 \%$ (cycle 4 ) for nitrogen.

According to the Brazilian Legislation $[32,33]$ the maximum permissible concentration for total amoniacal nitrogen is $20 \mathrm{mg} / \mathrm{L}$, regardless of the type of pollutant source. The concentration of ammoniacal nitrogen in the final effluent of this experiment remained below this limit, with an average value of $7.73 \pm 6.8 \mathrm{mg} / \mathrm{L}$.

The participation of fungi was predominant throughout the treatment process. At the end of the reactor operation, the fungal population was almost double that of bacterial, with 1,365,000 CFU/ml. Another fact that endorsed the effective participation of the fungi was that the bacteria could contribute to the increase of the nitrate concentration in the medium when nitrification was carried out[34]. However, this did not occur in the present study, with nitrate removal of $91 \%$, attributed to the dissimilatory activity of nitrate carried out by fungi.

The population of bacteria in the reactor apparently was not able to inhibit the enzymatic activity of the fungi. Scanning electron microscopy (SEM) images (Figure 5) confirmed that the fungal community occupied 
all the spaces of the polyurethane foam $(A)$, so that its growth was not restricted only to the surface of the support material, indicating that the polyurethane foam has been shown to be a good carrier with excellent surface area for biofilm fixation.

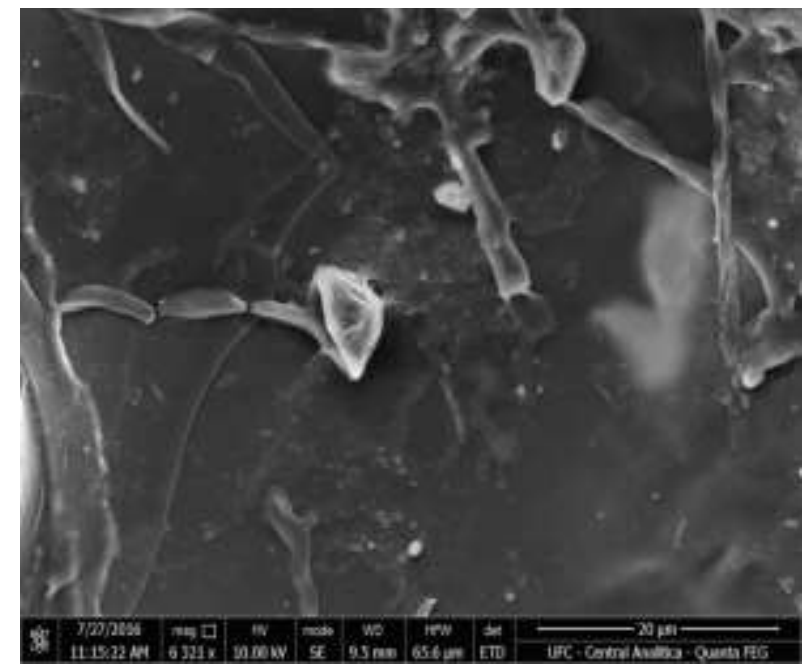

(a)

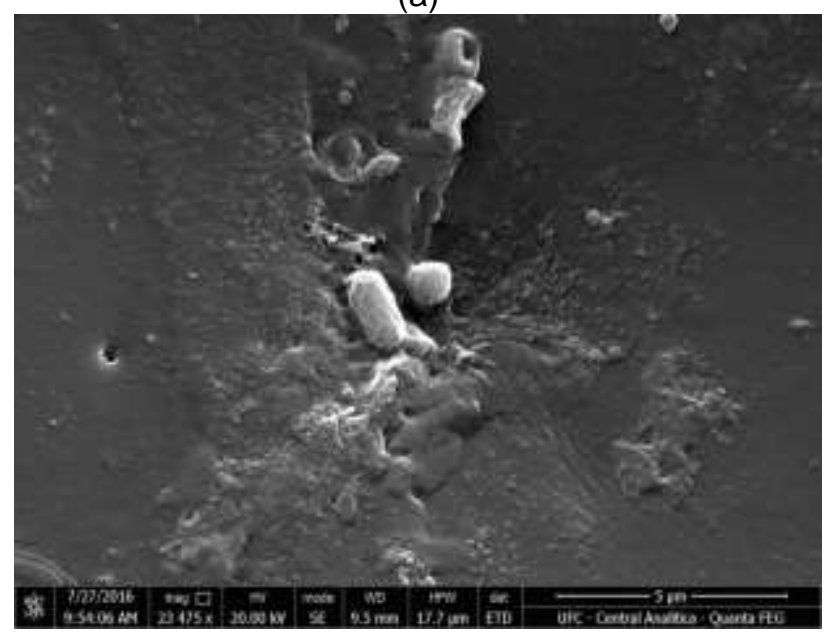

(c)

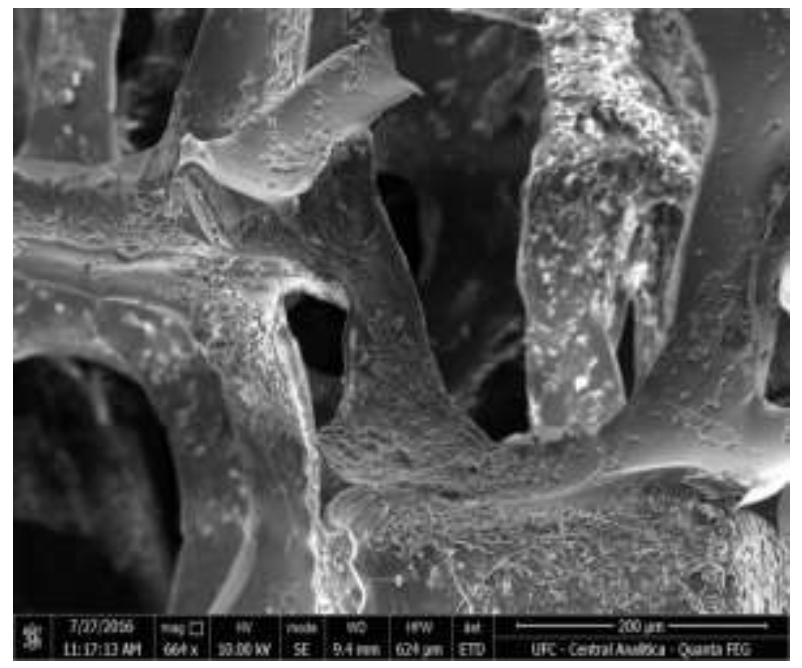

(b)

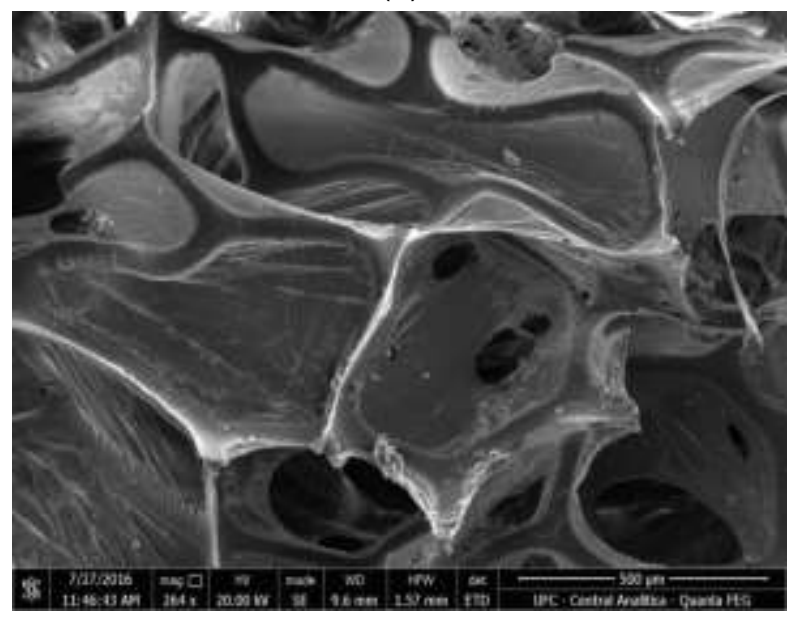

(d)

Figure 5. Scanning Electron Microscopy (SEM) showing the grown, immobilization and adhesion of microorganisms in the polyurethane foam $(\mathrm{a} / \mathrm{b} / \mathrm{c})$ and the presence of structures of coccis and bacilli (c).

SEM images allowed observing the formation of septate hyphae, characteristic of filamentous growth (b) in relation to the bacterial community in the reactor with structures of cocci and bacilli (c), as well as the form of adhesion of the microorganisms in the support material (d).

\section{DISCUSSIONS}

The semibatch reactor used was efficient in the removal of indigo carmine dye in all operating cycles. Almost $100 \%$ of the dye was removed at the first operation cycle, which can be explained by the adsorption process of the dye in the biomass and / or in the support medium.

Dye adsorption usually occurs in the initial periods of operation. This can be explained as by the reactor startup the support material has its available surface are quickly occluded by the dye. The mycelium also adsorbs the dye and dye adsorption occurs parallel to the dye biosorption by fungi [34,35].

After the initial cycles the dye removal presented values with small variations. From cycle 4 to cycle 12 the mean dye removal efficiency was $83 \pm 8 \%$. The main route of removal was by biosorption, since the foam saturation occurs at the first reaction cycle and a portion of dye adsorbed to the fungal biofilm was small $(0.27 \%)$. Many studies have reported the fungal ability to remove dyes by biosorption,[36] reported $74 \%$ of Remazol Brilliant Blue R removal by Aspergillus sp. 605 occurred via biosorption, [37] achieved 91.35\% 
removal of Congo red by Penicillium janthinellun, and achieved $60 \%$ removal by biosorption using Aspergillus niger [38].

The biosorption is considered the first step of the mycoremediation. Thus, the color removal depends both on the enzymatic production and on the biomassa yield, where the high biomass production contributes to the biosorption of the dyes [36].

The influence of adsorption on dye removal at the beginning of reactor operation was reported by [39] when studying the removal efficiency of Remazol Red dye in a continuous upflow reactor inoculated with a microbial consortium of bacteria (Brevibacillus laterosporus) and yeast (Brevibacillus laterosporus). They used different immobilization matrices (polyvinyl alcohol, stainless steel sponge, polyurethane foam and calcium alginate) in their study. The authors reported that during the first cycles the cells immobilized on polyurethane foam showed $96 \%$ of dye removal and only after the first cycles did the microbial communities remove dye by the production of extracellular enzymes necessary for the biodegradation.

Kurade and coauthors [39] also carried out a test containing only the dye and support material without addition of the microorganisms to reactional medium to observe the influence of the abiotic processes in the removal of the pollutant. According to this test, the polyurethane foam showed $5 \%$ discoloration in 16 hours, indicating the saturation of the support material. The authors concluded that the biodegradation process was superior to the adsorption removal in the polyurethane foam, with the adsorption having the greatest impact only in the initial phase of the reactor operation due to the larger pore size of the foam, which facilitates mass transfer.

Biodegradation process can occur in parallel to the biosorption and not only after it. The microbial action should not be disregarded in the pollutant removal during the reactor initial cycles. The microbial biodegradation is mediated by the release of extracellular enzymes that break down chemical bonds with formation of smaller molecules that can be assimilated by the fungi. Thus, the dye is used as a carbon source by the microorganism [40], which is the explanation for good removal values of the indigo carmine obtained throughout this study.

Cycles 5 and 7 showed residual dye concentration. The possible explanation for these removal values is the fungi used the nutrients available in the medium, which induced the enzymatic production that was used in the metabolization of the substrate or residual dye. There was an increase in removal efficiency from 35 for $76 \%$ in cycle 5 and from 59 to $76 \%$ in cycle 7 after 48 hours of the reactor operation. Such behavior was also reported by de Miranda [41] using the Curvularia lunata URM 6179 in the treatment of textile effluent for removal of indigo in static aerobic bioreactor. The authors obtained a constant dye removal of $58 \%$ from the first to the sixth day of treatment, which reached $96 \%$ after the tenth day of treatment.

Residual dye concentration may also be related to toxicity. According to Pizato [42] the increase in toxicity after treatment may be related to several factors, among them the formation of byproducts of fungal metabolism, partial degradation of the dye and consequently the formation of intermediate compounds and the decrease of $\mathrm{pH}$ of the medium. A production of mutagenic compounds was observed from the biodegradation of the dye by Phaneroachete chrysosporium URM 6181 [41].

None of the operating cycles showed increased dye concentration in the final effluent. Isatin and isatin sulfonic acid are the main intermediates formed by the degradation of the indigo dye. Isatin is produced by the rupture of the double bond between carbons of the dye. Isatin is rapidly converted to isatin sulfonic acid by addition of water and the formation of the double bond between carbon and oxygen through oxidative process [24,43].

COD removal followed the dye removal in the médium, the simultaneous removal of COD and dye in medium containing glucose was also reported by Senthilkumar and coauthors [44] evaluated the potential for discoloration of Starch Black 10B (1g) by Phanerochaete chrysosporium, achieving $97 \%$ dye removal in seven days, when $0.5 \mathrm{~g} / \mathrm{L}$ of glucose was added to the reactional medium. The good results were attributed to the addition of glucose in the medium, which was essential for the degradation of the dye molecules.

Glucose is a primary source of carbon that contributed in dye removal by reacting with enzymes to form metabolites that aided in the discoloration of the dye. This process favored the increase of biomass in the reactor. However, glucose must be present in the medium in adequate concentrations. The excess of glucose in the medium would inhibit the consumption of the indigo carmine, which has a more complex structure [44], but this was not observed in this study.

The aid of glucose in dye discoloration could be observed after 24 hours reaction time. COD values upon completion of 48 hours of operation indicate that the presence of glucose was beneficial to the treatment.

COD removal in cycles $3(64 \%), 4(82 \%), 5(80 \%)$ and $10(87 \%)$ after 24 hours of reaction were higher than those recorded in the 48 hours of reaction in other cycles. It was observed that in these cycles the 
concentration of dye after 24 hours of treatment was lower than the average values obtained for the final effluent (FRT), which was $5.77 \pm 3.5 \mathrm{mg} / \mathrm{L}$. Indigo dye concentrations in these cycles after 48 hours of reaction were $7.8 \mathrm{mg} / \mathrm{L}$ (cycle 3), $6.5 \mathrm{mg} / \mathrm{L}$ (cycle 4), $13.17 \mathrm{mg} / \mathrm{L}$ (cycle 5) and $6.6 \mathrm{mg} / \mathrm{L}$ (cycle 10).

The fungus did not consume all the organic matter in the form of dye present in the medium. This can be explained by the addition of glucose after the first $24 \mathrm{~h}$ of reaction. Thus, there was a greater supply of carbon sources and dye / glucose ratio (6.0:0.58). The use of the dye was inhibited because the glucose was favorably assimilated, which may have reflected in the removal of COD in these cycles. In this condition, the fungi possibly chose to consume the glucose that is a source of carbon of easy assimilation over the dye.

The fungal ability of Trametes villosa SCS-10 for dye discoloration using wastewater with different dye concentrations (350-500 mg/ and over $500 \mathrm{mg} / \mathrm{L}$ ) for two different dyes (Acid Red 357 and Acid Orange 142) and three conditions of nutrient supplementation under submerged fermentation conditions with a 10 day reaction time was evaluated [29]. A COD removal efficiency decrease was observed when the medium was rich in glucose $(1 \%)$ and malt extract $(2 \%)$ showing a COD removal efficiency of less than $45 \%$, regardless of the dye concentration in the medium. The largest COD removal $(74 \pm 3.1 \%)$, was registered with the reduced supplementation medium ( $0.5 \%$ glucose and $1 \%$ malt extract).

Glucose presence after 48 hours of operation was observed, although in a small concentration, with na average of $0.039 \mathrm{mg} / \mathrm{L}$. Thus, both dye and glucose consumptions were inhibited. This may suggest that the biodegradation process may be associated with the production of toxic compounds[45].

The reduction of dye removal efficiency in the biological system can be attributed to the recalcitrance of compounds from the rupture reactions of its molecule that occurred after the first 24 hours of operation. Possibly, with the rupture of the chromophore group, the benzene group was released from the dye molecule, which, due to its recalcitrance, would not have been totally biodegraded. Thus, the accumulation of byproducts generated from the degradation of the dye, such as benzene, would have contributed to the increase of COD, particularly in the cycles that presented lower removal efficiency as in cycles 3, 4 and 5.

The $\mathrm{pH}$ values in the reactor remained in the acidic range during all the operational cycles. This was good for the fungi metabolism, as the ideal $\mathrm{pH}$ range from 4.0 to 6.0 for the performance of the enzymes involved in the biodegradation process [46]. It has been reported that the process of dye biodegradation depends mainly on the enzymes produced by fungi, such as lignin peroxidase (LiP), manganese peroxidase $(\mathrm{MnP})$ and laccase, which comprises an enzymatic oxidative-lignolytic system $[47,48]$.

The final effluent of the cycles presented an average $\mathrm{pH}$ of $2.57 \pm 0.36$. The decay of the $\mathrm{pH}$ values occurred in parallel with the dye removal, both in the 24 hours of reaction (IRT) and at the end of the 48 hours reaction (FRT) operation cycles. The maintenance of $\mathrm{pH}$ values in the acidic range during the reaction time is related to the presence of organic acids of low molecular weight, due to the degradation of the molecule of the dye and the presence of glucose in the medium. Moreover, this condition also favors the process of adsorption of the dye $[49,50]$, another route of removal of the pollutant from the medium.

Adsorption of the dye to the biofilm and the support material is influenced by the $\mathrm{pH}$ of the medium. This variable may affect the surface charge of the adsorbent, because when the $\mathrm{pH}$ assumes values within the acid range more protons will be available on the adsorbent surfaces. This condition favors electrostatic attraction between dye anions and positively adsorbent charged sites. At high $\mathrm{pH}$ values $(\mathrm{pH}>7)$, the carmine indigo is deprotonated and the electrostatic repulsion forces may adversely affect the adsorption. The opposite occurs with low $\mathrm{pH}$ medium in which the dye is protonated and interacts with the adsorbent negative charge groups [51,52].

The system was efficient in removing nitrogen, Due to the readjustment of glucose in the intermediate reaction time (IRT) there was greater availability of this cosubstrate in the medium. This would have contributed to the greater removal of ammoniacal nitrogen, since the ammonium ions, stored inside the fungal cell, react with glucose to form glucosamine. In this process, there is release of $\mathrm{H}+$ out of the cell [53], which also contributed to the decrease of the $\mathrm{pH}$ of the medium.

The presence of a primary source of carbon, such glucose, is very importante for removal of nitrogen, since this exerts influence on the process of $\mathrm{NH}_{4}$ removal by fungi. Liu and coauthors [54] was observed ammonium + removal by Paecilomyces variotii with varied parameters such as temperature, $\mathrm{pH}$, carbon sources and $\mathrm{C} / \mathrm{N}$ ratio in batch aerated reactors. The best condition for ammonium removal was at the presence of glucose $(\mathrm{C} / \mathrm{N} 10-40)$ and $\mathrm{pH}$ ranging from acid to neutral (4 to 7$)$, at a temperature of $25^{\circ}$ to $37^{\circ} \mathrm{C}$.

Although ammoniacal nitrogen was readily used by fungi in the present study, its presence did not inhibit the use of nitrate and nitrite. They were simultaneously removed in the reactor. Thus, the use of 
Phanerochaete chrysosporium immobilized in a reactor operated in semibatch with addition of glucose was also promising in the removal of this nutrient from the medium.

Maintenance of aseptic conditions was not a goal in the study, since it did not correspond to field conditions. The combination of fungi and bacteria is feasible for the removal of complex substances from an effluent, since pure cultures have limited capacity to metabolize organic compounds and require sterile conditions. Thus, the coexistence of fungi and bacteria in the medium suggests interactions that may be important to improve biological degradation [55].

Polyurethane foam is considered a good support medium as it does not require chemical reagents to prepare the surface of the material to facilitate adhesion of the microorganisms. It is a material that presents a porosity of $73 \pm 1 \%$. This characteristic favors the diffusion of oxygen and nutrients to the fungal cells, optimizing the enzymatic and biomass production [56].

SEM images allowed observing the formation of septate hyphae. Inside the fungal hyphae there are extracellular enzymes which initiate the degradation of dye, first by adsorption onto the surface and second by the breaking of chemical bonds in dye molecules [57].

The use of polyurethane foam as support medium to fungal biofilm still reduces the bioreactor starting time, since its characteristics favor the fast adhesion of the microorganisms to its surface [58]. In addition, the polyurethane provides resistance to the fungal community by protecting it from environmental stresses, such as the presence of toxic molecules [45], improving the biosorption of the dye by the fungi.

\section{CONCLUSIONS}

The bioreactor with Phanerochaete chrsosporyum operated in semibatch had a good performance in the removal of dye (85\%), organic matter (74\%), ammonia (85\%), nitrite $(83 \%)$ and nitrate $(81 \%)$.

However, the mineralization of the dye was not complete, since the scan indicated the formation of byproducts, possibly isatin sulfonic acid, by band at $245 \mathrm{~nm}$. Since byproducts can be toxic to microorganisms, some of them may have caused an inhibition of dye consumption within 24 hours after glucose addition. Glucose addition was pertinent to the maintenance of dye removal in the medium, since the removals followed until the last hours of reaction, according to the final results, achieving an average dye removal efficiency of $72 \pm 17 \%$ after 24 hours and $84 \pm 10 \%$ within 48 hours.

The reactor was contaminated by bacteria, forming a microbial consortium in which the fungal community predominated indicating the effective participation of fungi in the process of dye biodegradation.

The fungi adhered well to the polyurethane foam and colonized all the support material, not being restricted to the surface layer, which resulted in high concentration of fungi in the reactor.

The operation of the semibatch reactor allowed to increase the efficiency of dye removal from $72 \% \pm 17 \%$ to $84 \% \pm 10 \%$ and produced a final effluent with $3.35 \pm 1.99 \mathrm{mg} / \mathrm{L}$ of indigo carmine. In addition, the microorganisms had glucose for a longer time, which favored the removal of ammoniacal nitrogen to levels acceptable by the brazilian legislation.

Acknowledgments: To the Coordination for the Improvement of Higher Education Personnel (CAPES) for the financial aid to this project, the Environmental Technology Laboratory (LATAM) and to Central Analytical of Federal Univercity of Ceará (UFC) for aid in the analyses performed in this research.

\section{REFERENCES}

1. Melo GG, Braz CC, Amador VC, Dias EC, Almeida ES, Silva DPD. Estudos preliminares sobre atividade adsortiva do corante vermelho congo pelo fungo Lentinus crinitus. Rev Saúde e Ciência. 2014;3:312-20.

2. Baêta BE. Tratamento de efluentes de indústria têxtil utilizando reatores anaeróbios de membranas submersas(SAMBR) com e sem carvão ativado em pó (CAP). Dissertação (Mestrado)-. Instituto de ciências exatas e biológicas. Universidade Federal de Ouro Preto; 2012.

3. Kunz A, Peralta-Zamora P, Moraes SG de, Durán N. Novas tendências no tratamento de efluentes têxteis. Quim Nova. 2002;25(1):78-82.

4. Bankole PO, Adekunle AA, Obidi OF, Olukanni OD, Govindwar SP. Degradation of indigo dye by a newly isolated yeast, Diutina rugosa from dye wastewater polluted soil. Biochem Pharmacol [Internet]. 2017; Available from: http://dx.doi.org/10.1016/j.jece.2017.08.050

5. Haq I, Kumar S, Kumari V, Singh SK, Raj A. Evaluation of bioremediation potentiality of ligninolytic Serratia liquefaciens for detoxification of pulp and paper mill effluent. J Hazard Mater [Internet]. 2016 Mar;305:190-9. Available from: https://linkinghub.elsevier.com/retrieve/pii/S0304389415302466

6. Sen KS, Raut S, Bandyopadhyay P, Raut S. Fungal decolouration and degradation of azo dyes : A review. Fungal 
Biol Rev [Internet]. 2016; Available from: http://dx.doi.org/10.1016/j.fbr.2016.06.003

7. Ghasemi F, Tabandeh F, Bambai B, Sambasiva Rao KRS. Decolorization of different azo dyes by phanerochaete chrysosporium RP78 under optimal condition. Int J Environ Sci Technol. 2010;7(3):457-64.

8. Espinosa-Ortiz EJ, Rene ER, Pakshirajan K, van Hullebusch ED, Lens PNL. Fungal pelleted reactors in wastewater treatment: Applications and perspectives. Chem Eng J. 2016;283:553-71.

9. Solís M, Solís A, Inés H, Manjarrez N, Flores M. Microbial decolouration of azo dyes : A review. Process Biochem [Internet]. 2012;47(12):1723-48. Available from: http://dx.doi.org/10.1016/j.procbio.2012.08.014

10. Sharari M, Roohani M, Latibari AJ, Guillet A, Aurousseau M, Sharari A. Treatment of bagasse preparation effluent by Phanerochaete chrysosporium immobilized on polyurethane foam: Enzyme production versus pollution removal. Ind Crop Prod [Internet]. 2013;46:226-33. Available from: http://dx.doi.org/10.1016/j.indcrop.2013.02.001

11. Singh P. Mycoremediation: Fungal Bioremediation. Canadá: Wiley; 2006. 617 p.

12. Khehra MS, Saini HS, Sharma DK, Chadha BS, Chimni SS. Comparative studies on potential of consortium and constituent pure bacterial isolates to decolorize azo dyes. Water Res [Internet]. 2005 Dec;39(20):5135-41. Available from: https://linkinghub.elsevier.com/retrieve/pii/S0043135405005531

13. Sanghi R, Dixit A, Verma P. Evaluation of Coriolus versicolor for its tolerance towards toxic sulphonic azo dyes in sequential batch mode. Process Saf Environ Prot [Internet]. 2011 Jan;89(1):15-21. Available from: https://linkinghub.elsevier.com/retrieve/pii/S0957582010000893

14. Singh G, Dwivedi SK. Decolorization and degradation of Direct Blue-1 (Azo dye) by newly isolated fungus Aspergillus terreus GS28, from sludge of carpet industry. Environ Technol Innov [Internet]. 2020 May;18:100751. Available from: https://linkinghub.elsevier.com/retrieve/pii/S2352186419307576

15. Moda EM, Horii J, Spoto MHF. Edible mushroom Pleurotus sajor-caju production on washed and supplemented sugarcane bagasse. Sci Agric [Internet]. 2005 Apr;62(2):127-32. Available from: http://www.scielo.br/scielo.php?script=sci_arttext\&pid=S0103-90162005000200006\&lng=en\&tlng=en

16. Maciel GM. Desenvolvimento de bioprocesso para produção de xilenases por fermentação no estado sólido utilizando bagaço de cana de açúcar e farelo de soja. Universidade Federal do Paraná, Curitiba; 2006.

17. Louguercio L.; Esposito E. Fungos: estrutura e ultra-estrutura. In: Sul C do, editor. Fungos: uma introdução à biologia, bioquímica e biotecnologia. Caxias do Sul; 2004. p. 12-44.

18. Yang Q, TAO L, Yang M, Zhang H. Effects of glucose on the decolorization of Reactive Black 5 by yeast isolates. J Environ Sci. 2008;20:105-8.

19. Andrade MVF, Leite A, Máximo H de O, Wanderley CRP, Silva GMM, Rodrigues K. Use of white rot fungi in biodegradation of the textile dye in sequencing batch reactor. AIDIS. 2015;8(2):220-36.

20. APHA. Standard methods for water and wastewater examination, 21th ed., American Public Health Association, Washington, DC, USA. 2005.

21. Rodier J. L'analyse de L'eau: eaux naturelles, eaux residuls, eaux de mer. 6th ed. Paris: Dunod Tecnique; 1978. $1135 \mathrm{p}$.

22. Rodrigues KA. Uso de reatores biológicos com fungos para remoção de fenol de água residuária sintética. Universidade de São Paulo; 2006.

23. Trigueiros DEG. Avaliação da Cinética de Biodegradação dos Compostos Tóxicos: Benzeno, Tolueno, Etilbenzeno, Xileno (BTEX) e Fenol. Universidade Estadual do Oeste do Paraná), Curitiba; 2008.

24. Zaied M, Chutet E, Peulon S, Bellakhal N, Desmazières B, Dachraoui M, et al. Spontaneous oxidative degradation of indigo carmine by thin films of birnessite electrodeposited onto SnO2. Appl Catal B Environ [Internet]. 2011 Aug;107(1-2):42-51. Available from: https://linkinghub.elsevier.com/retrieve/pii/S0926337311003110

25. Da Silva KML, Wanderley CRP, Marinho G, Oliveira JC de, Santos ADO, Rodrigues K. Influência do excesso de nitrogênio amoniacal no tratamento de efluente têxtil em reator de bateladas sequenciais com Aspergillus niger AN 400. Eng Sanit e Ambient [Internet]. 2015 Dec;20(4):635-43. Available from: http://www.scielo.br/scielo.php?script=sci_arttext\&pid=S1413-41522015000400635\&lng=pt\&tlng=pt

26. Ma L, Zhuo R, Liu H, Yu D, Jiang M, Zhang X, et al. Efficient decolorization and detoxification of the sulfonated azo dye Reactive Orange 16 and simulated textile wastewater containing Reactive Orange 16 by the white-rot fungus Ganoderma sp. En3 isolated from the forest of Tzu-chin Mountain in China. Biochem Eng J. 2014;82:1-9.

27. Arikan EB, Isik Z, Bouras HD, Dizge N. Investigation of immobilized filamentous fungi for treatment of real textile industry wastewater using up flow packed bed bioreactor. Bioresour Technol Reports [Internet]. 2019;100197. Available from: https://doi.org/10.1016/j.biteb.2019.100197

28. Manai I, Miladi B, El Mselmi A, Smaali I, Ben Hassen A, Hamdi M, et al. Industrial textile effluent decolourization in stirred and static batch cultures of a new fungal strain Chaetomium globosum IMA1 KJ472923. J Environ Manage [Internet]. 2016 Apr;170:8-14. Available from: https://linkinghub.elsevier.com/retrieve/pii/S0301479715304539

29. Ortiz-Monsalve S, Valente P, Poll E, Jaramillo-garc V, Henrique JA, Gutterres M. Biodecolourization and 
biodetoxification of dye-containing wastewaters from leather dyeing by the native fungal strain Trametes villosa SCS-10. Biochem Eng J [Internet]. 2018; Available from: https://doi.org/10.1016/j.bej.2018.10.002

30. Kamida HM, Durrant LR, Monteiro RTR, Armas ED de. Biodegradação de efluente têxtil por Pleurotus sajor-caju. Quim Nova [Internet]. $2005 \quad$ Aug;28(4):629-32. Available from: http://www.scielo.br/scielo.php?script=sci_arttext\&pid=S0100-40422005000400014\&lng=pt\&nrm=iso\&tlng=pt

31. Kaushik P, Malik A. Fungal dye decolourization: Recent advances and future potential. Environ Int. 2009;35(1):127-41.

32. Conselho Nacional do Meio Ambiente- CONAMA. Resolução N 430, De 13 De Maio De 2011. 2011;8. Available from: http://www.mma.gov.br/port/conama/legiabre.cfm?codlegi=646

33. Superintendência Estadual do Meio Ambiente -SEMACE. Resolução COEMA №2, de 02 de fevereiro de 2017. [Internet]. $2017 \quad$ p. $56-61 . \quad$ Available from: https://www.semace.ce.gov.br/wpcontent/uploads/sites/46/2019/09/COEMA-02-2017.pdf

34. Santos ADO, Souza AM, Barreto I, Rodrigues K, Marinho G, Wanderley CRP. Degradação de índigo carmim em reator em bateladas sequenciais com aspergillus niger AN400 no tratamento de água residuárias têxtil in natura. AIDIS, V.8,N.3, P. 3328-343. AIDIS. 2015;8(3).

35. Schio R, Bruno C, Gonçalves JO, Pinto LAA, Mallmann ES, Dotto GL. Synthesis of a bio - based polyurethane / chitosan composite foam using ricinoleic acid for the adsorption of Food Red 17 dye. Int J Biol Macromol [Internet]. 2019;121:373-80. Available from: https://doi.org/10.1016/j.jibiomac.2018.09.186

36. Noman E, Talip BA, Al-Gheethi A, Mohamed R, Nagao H. Decolourisation of dyes in greywater by mycoremediation and mycosorption process of fungi from peatland; primary study. Mater Today Proc [Internet]. 2020 Feb; Available from: https://linkinghub.elsevier.com/retrieve/pii/S2214785320301395

37. Wang M-X, Zhang Q-L, Yao S-J. A novel biosorbent formed of marine-derived Penicillium janthinellum mycelial pellets for removing dyes from dye-containing wastewater. Chem Eng J [Internet]. 2015 Jan;259:837-44. Available from: https://linkinghub.elsevier.com/retrieve/pii/S1385894714010547

38. Mahmoud MS, Mostafa MK, Mohamed SA, Sobhy NA, Nasr M. Bioremediation of red azo dye from aqueous solutions by $A$ spergillus niger strain isolated from textile wastewater. J Environ Chem Eng [Internet]. 2017 Feb;5(1):547-54. Available from: https://linkinghub.elsevier.com/retrieve/pii/S2213343716304742

39. Kurade MB, Waghmode TR, Xiong J, Govindwar SP, Jeon B-H. Decolorization of textile industry effluent using immobilized consortium cells in upflow fixed bed reactor. J Clean Prod. 2018;

40. Khelifi E, Gannoun H, Touhami Y, Bouallagui H, Hamdi M. Aerobic decolourization of the indigo dye-containing textile wastewater using continuous combined bioreactors. 2008;152:683-9.

41. De Miranda R de C, Gomes E de B, Pereira Júnior N, Marin-Morales MA, Machado KMG, Gusmão NB, et al. Biotreatment of textile effluent in static bioreactor by Curvularia luneta URM 6179 and Phanerochaete chrysosporium URM 6181. Bioresour Technol. 2013;

42. Pizato E, Lopes AC, Rocha RDC, Barbosa ADM, Cunha MA. Caracterização de efluente têxtil e avaliação da capacidade de remoção de cor utilizando o fungo Lasiodiplodia theobromae MMPI. Rev Eng Sanitária e Ambient. 2017;1027-35.

43. Li H-X, Xu B, Tang L, Zhang J-H, Mao Z-G. Reductive decolorization of indigo carmine dye with Bacillus sp. MZS10. Int Biodeterior Biodegradation [Internet]. 2015 Sep;103:30-7. Available from: https://linkinghub.elsevier.com/retrieve/pii/S0964830515001225

44. Senthilkumar S, Perumalsamy M, Janardhana Prabhu H. Decolourization potential of white-rot fungus Phanerochaete chrysosporium on synthetic dye bath effluent containing Amido black 10B. J Saudi Chem Soc [Internet]. 2014;18(6):845-53. Available from: http://dx.doi.org/10.1016/j.jscs.2011.10.010

45. Przystas W, Zabłocka-godlewska E, Grabinska-Sota E. Efficiency of decolorization of different dyes using fungal biomass immobilized on different solid. Brazilian J Microbiol. 2017;1-11.

46. Griffin D. Fungal Physiology. New York: Wiley-Liss; 1994. 458 p.

47. Singh LR, Singh K, Pratap R. Enzymatic decolorization and degradation of azo dyes - A review. Int Biodeterior Biodegrad [Internet]. 2015;104:21-31. Available from: http://dx.doi.org/10.1016/j.ibiod.2015.04.027

48. Wang N, Chu Y, Wu F, Zhao Z, Xu X. Decolorization and degradation of Congo red by a newly isolated white rot fungus, Ceriporia lacerata , from decayed mulberry branches. Int Biodeterior Biodegradation. 2017;117:236-44.

49. Khelifi E, Touhami $\mathrm{Y}$, Bouallagui $\mathrm{H}$, Hamdi M. Biosorption of indigo from aqueous solution by dead fungal biomass Aspergillus alliaceus. Desalin Water Treat [Internet]. 2013 Oct 14;1-9. Available from: http://www.tandfonline.com/doi/abs/10.1080/19443994.2013.850745

50. Andrade MVF, da Silva KML, Siqueira JP da S, Wanderley CRP, Araújo R dos S, Marinho G, et al. Azo dye degradation by phanerochaete chrysosporium in the medium enriched with nitrogen in the presence of primary cosubstrate. Brazilian Arch Biol Technol. 2013;56(5):867-74. 
51. Zhang Y, Huang G, An C, Xin X, Liu X, Raman M, et al. Transport of anionic azo dyes from aqueous solution to gemini surfactant-modified wheat bran: Synchrotron infrared, molecular interaction and adsorption studies. Sci Total Environ [Internet]. 2017 Oct;595:723-32. Available from: https://linkinghub.elsevier.com/retrieve/pii/S0048969717308598

52. Almeida EJR, Corso CR. Comparative study of toxicity of azo dye Procion Red MX-5B following biosorption and biodegradation treatments with the fungi Aspergillus niger and Aspergillus terreus. Chemosphere [Internet]. 2014;112:317-22. Available from: http://dx.doi.org/10.1016/j.chemosphere.2014.04.060

53. Papagianni M, Wayman F, Mattey M. Fate and Role of Ammonium lons during Fermentation of Citric Acid by Aspergillus niger. Appl Environ Microbiol [Internet]. 2005 Nov;71(11):7178-86. Available from: https://aem.asm.org/content/71/11/7178

54. Liu Y, Hu T, Zhao J, Lv Y, Ren R. Simultaneous removal of carbon and nitrogen by mycelial pellets of a heterotrophic nitrifying fungus-Penicillium sp. L1. J Biosci Bioeng [Internet]. 2017 Feb;123(2):223-9. Available from: https://linkinghub.elsevier.com/retrieve/pii/S1389172316302122

55. Dios MÁF de, Campo AG del, Fernández FJ, Rodrigo M, Pazos M, Sanromán MÁ. Bacterial-fungal interactions enhance power generation in microbial fuel cells and drive dye decolourisation by an ex situ and in situ electroFenton process. Bioresour Technol [Internet]. 2013 Nov;148:39-46. Available from: https://linkinghub.elsevier.com/retrieve/pii/S096085241301314X

56. Liang J, Chiaw LKC, Ning X. Application of biological activated carbon as a low pH biofilter medium for gas mixture treatment. Biotechnol Bioeng [Internet]. 2007 Apr 15;96(6):1092-100. Available from: http://doi.wiley.com/10.1002/bit.21203

57. Insanullah I, Jamal A, llyas M, Zubair M, Khan G, Atieh MA. Bioremediation of dyes: Current status and prospects. J Water Process Eng [Internet]. 2020;38(October):101680. Available from: https://doi.org/10.1016/j.jwpe.2020.101680

58. Gutiérrez-Acosta OB, Arriaga S, Escobar-Barrios VA, Casas-Flores S, Almendarez-Camarillo A. Performance of innovative PU-foam and natural fiber-based composites for the biofiltration of a mixture of volatile organic compounds by a fungal biofilm. J Hazard Mater [Internet]. 2012 Jan;201-202:202-8. Available from: https://linkinghub.elsevier.com/retrieve/pii/S0304389411014488.

(C) (1) 2021 by the authors. Submitted for possible open access publication under the terms and
conditions of the Creative Commons Attribution (CC BY NC) license
(https://creativecommons.org/licenses/by-nc/4.0/). 